\title{
Shrimp U-Pb age and Sr-Nd isotopes of the Morro do Baú mafic intrusion: implications for the evolution of the Arenópolis volcano-sedimentary sequence, Goiás Magmatic Arc
}

\author{
MÁRCIO M. PIMENTEL ${ }^{1}$, MARIA HELENA B.M. HOLLANDA ${ }^{1}$ \\ and RICHARD ARMSTRONG ${ }^{2}$ \\ ${ }^{1}$ Instituto de Geociências, Universidade de Brasília, 70910-900 Brasília, DF, Brasil \\ ${ }^{2}$ Research School of Earth Sciences, Australian National University, Canberra ACT 0200 Austrália \\ Manuscript received on July 17, 2002; accepted for publication on March 7, 2003; \\ contributed by MárCIO M. PimenteL*
}

\begin{abstract}
The Arenópolis volcano-sedimentary sequence is located in the southern part of the Goiás Magmatic Arc and includes a ca. 900 Ma calc-alkaline arc sequence made of volcanic rocks ranging in composition from basalts to rhyolites, metamorphosed under greenschist to amphibolite facies. Small calc-alkaline gabbro to granite sub-volcanic bodies are also recognized. The Morro do Baú intrusion is the largest of these intrusions, and is made of gabbros and diorites. Zircon grains separated from one gabbro sample and analyzed by SHRIMP I yielded the mean ${ }^{206} \mathrm{~Pb} /{ }^{238} \mathrm{U}$ age of $890+/-8 \mathrm{Ma}$, indicating that the intrusion is roughly coeval or only slightly younger than the Arenópolis volcanics.

Contrary to the metavolcanics, which are juvenile, the Nd isotopic composition of the Morro do Baú gabbro indicates strong contamination with archean sialic material $\left(\mathrm{T}_{\mathrm{DM}}\right.$ of $2.8 \mathrm{Ga}$ and $\operatorname{Epsilon}_{\mathrm{Nd}}(\mathrm{T})$ of -9.7$)$, represented in the area by an allochthonous sliver of archean/paleoproterozoic gneisses (Ribeirão gneiss) which are the country-rocks for the gabbro/dioritic intrusion. The emplacement age of ca. 890 Ma represents a minimum age limit for the tectonic accretion of the gneiss sliver to the younger rocks of the Arenópolis sequence. The data suggest that this happened early in the evolution of the Goiás Magmatic Arc, between ca. 920 and 890 Ma.
\end{abstract}

Key words: Goiás Magmatic Arc, Arenópolis, U-Pb SHRIMP, basic magmatism, crustal contamination.

\section{INTRODUCTION}

The Arenópolis volcano-sedimentary sequence is one of the supracrustal associations comprising the southern part of the Goiás Magmatic Arc. It includes a typical calc-alkaline arc-type volcanic sequence made of ca. $900 \mathrm{Ma}$ old metabasalts, metaandesites, metadacites and metarrhyolites, which have been intensely deformed and affected by Neo-

*Member of Academia Brasileira de Ciências Correspondence to: Márcio M. Pimentel

E-mail: marcio@unb.br/mmp1103@terra.com.br proterozoic (ca. $600 \mathrm{Ma}$ ) strike-slip shear zones (Pimentel et al. 1991). In association with the volcanic rocks, a number of small gabbroic to granitic plutons are recognized and were interpreted as the plutonic and sub-volcanic counterparts of the arc volcanics (Pimentel and Fuck 1986, 1987). In the southern part of the volcano-sedimentary sequence, the Morro do Baú gabbroic intrusion represents one of these bodies. It comprises deformed and metamorphosed gabbros and diorites, which locally display preserved ophitic textures and enclaves of fine- 
grained amphibolites.

This intrusion is exposed within the Ribeirão gneisses and is probably intrusive into them, although clear cross-cutting relationships are not observed due to poor exposure conditions. The Ribeirão gneiss represents a fault-bounded slice of older rocks (Archean Nd isotopic signature and Paleoproterozoic $\mathrm{Rb}-\mathrm{Sr}$ and $\mathrm{Pb}-\mathrm{Pb}$ isochrons) tectonically emplaced, probably during the Neoproterozoic, in between the younger supracrustals of the Arenópolis sequence. It has Archean $\mathrm{T}_{\mathrm{DM}}$ model ages but the Sm-Nd isotopic system has been severely disturbed during a ca. $800 \mathrm{Ma}$ event, as indicated by the Sm-Nd whole-rock isochron (Pimentel 1992).

In this study we present U-Pb SHRIMP zircon age and the $\mathrm{Sm}-\mathrm{Nd}$ isotopic characteristic of the Morro do Baú intrusion and discuss their significance for the tectonic evolution of the Arenópolis volcano-sedimentary sequence and the age of accretion to the Ribeirão gneiss to the younger terrains.

\section{REGIONAL GEOLOGY}

The westernmost part of the Brasília Belt, in central Brazil, consists of a large Neoproterozoic juvenile arc (Goiás Magmatic Arc) formed by arctype volcano-sedimentary rocks and tonalite/granodiorite gneisses. The main magmatic terrains are known as the Arenópolis and Mara Rosa arcs, located in western and northern Goiás, respectively (Pimentel and Fuck 1992, Fuck et al. 1994, Pimentel et al. 1997, 2000a,b) (Figure 1). In both areas, geological evolution started at ca. 900-860 Ma with the crystallization of very primitive calc-alkaline volcanics and associated tonalites/granodiorites such as the Arenópolis volcanics and orthogneisses $\left(\varepsilon_{\text {nd }}\right.$ values between ca. $+3,0$ and $+6,0$, and $\mathrm{T}_{\mathrm{DM}}$ values mostly between ca. 0,8 and $1,1 \mathrm{Ga}$; Pimentel et al. 1991, 1997, Pimentel and Fuck 1992, Pimentel et al. 2000a). Geochemical and isotopic data suggest that the original magmas formed above subduction zones where young and hot oceanic lithosphere was subducted under oceanic lithosphere, possibly, in an intraoceanic multi-arc system (Pimentel and Fuck 1992, Pimentel et al. 1997). Calc-alkaline ig- neous activity lasted until ca. $640 \mathrm{Ma}$, and the main deformational/metamorphic episode occurred at ca. $620 \mathrm{Ma}$, as indicated by a number of U-Pb titanite and Sm-Nd garnet ages (for a review, see Pimentel et al. 2000a). The detailed evolutionary history of the Goiás Magmatic Arc is not well known. It is likely that the period between 900 and $640 \mathrm{Ma}$ included events such as the growth and amalgamation of island arc systems, collision between arcs and between the arc the São Francisco continent, accompanied by various phases of metamorphism and deformation. In fact, in the northern part of the belt, a metamorphic episode of ca. 750 Ma has been identified in metasedimentary rocks within the Mara Rosa Arc. This has been preliminarily interpreted as indicative of the accretion of the arc to the western margin of the continent (Junges et al. 2002). Similar metamorphic ages have not yet been identified in the southern part of the arc.

This latest and most obvious deformational event affecting rocks of the Goiás Magmatic Arc was responsible for the development of: (i) W-NW dipping foliation showing kinematic indicators revealing tectonic transport to the east (e.g. in the Mara Rosa arc area), and (ii) wide and long subvertical, dominantly NE-trending mylonite zones, such as the Transbrasiliano Lineament (Figure 1). This was accompanied and followed by extensive crustal re-melting and emplacement of large late- to postorogenic K-rich granitic intrusions (Pimentel et al. 1996) such as the Serra do Iran and Caiapó granite intrusions (Figure 2) and associated mafic bodies and small layered mafic-ultramafic complexes.

\section{The Arenópolis Volcano-Sedimentary Sequence}

The Arenópolis volcano-sedimentary sequence (Pimentel and Fuck 1986) is made of two distinct units (Figure 2):

1. The Córrego da Onça Unit forms a narrow strip of sheared metavolcanic and metaplutonic rocks in the eastern part of the sequence. It includes metabasalts, meta-andesites, meta- 


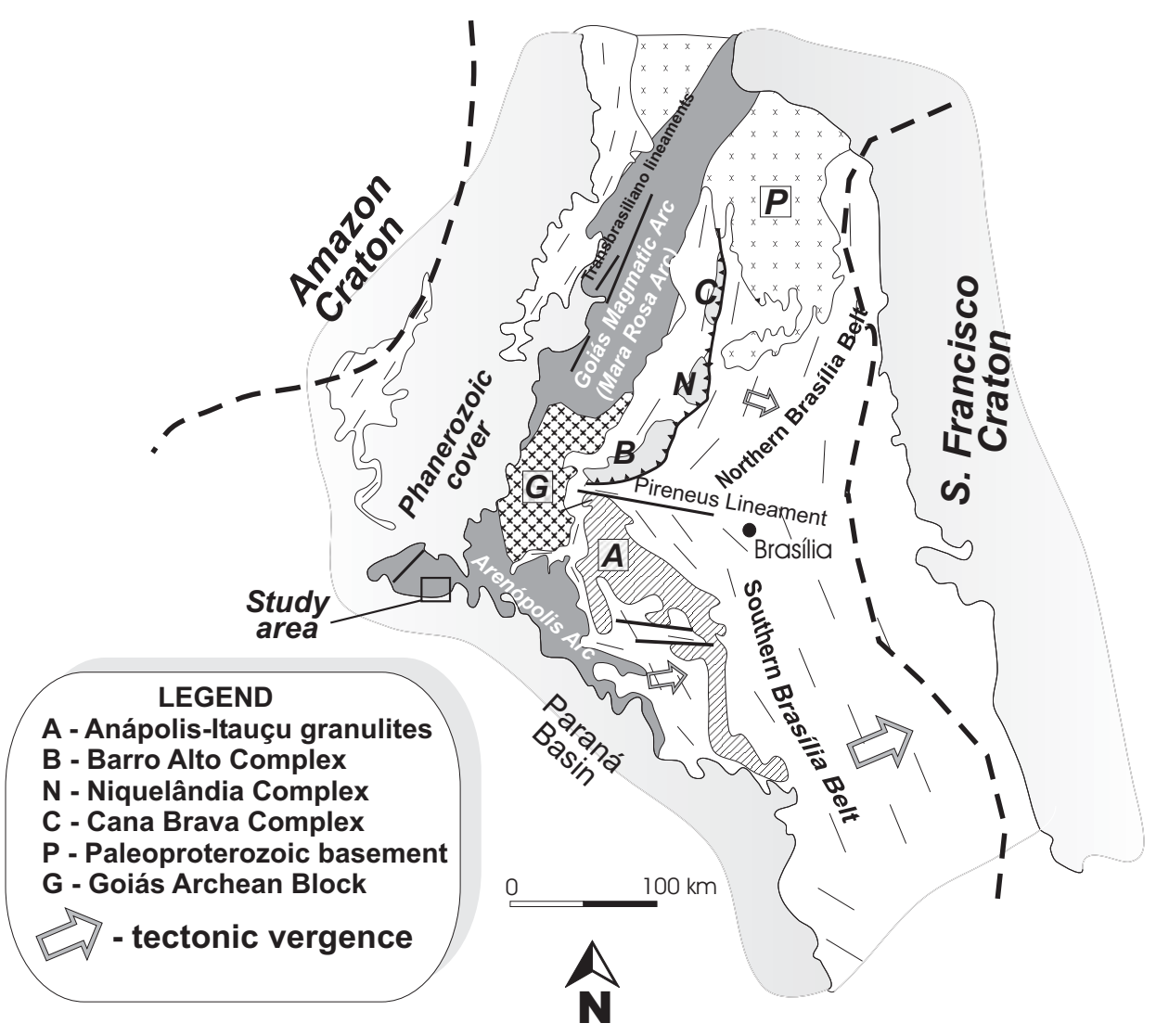

Fig. 1 - Main tectonic features of the eastern part of the Tocantins Province, in central Brazil.

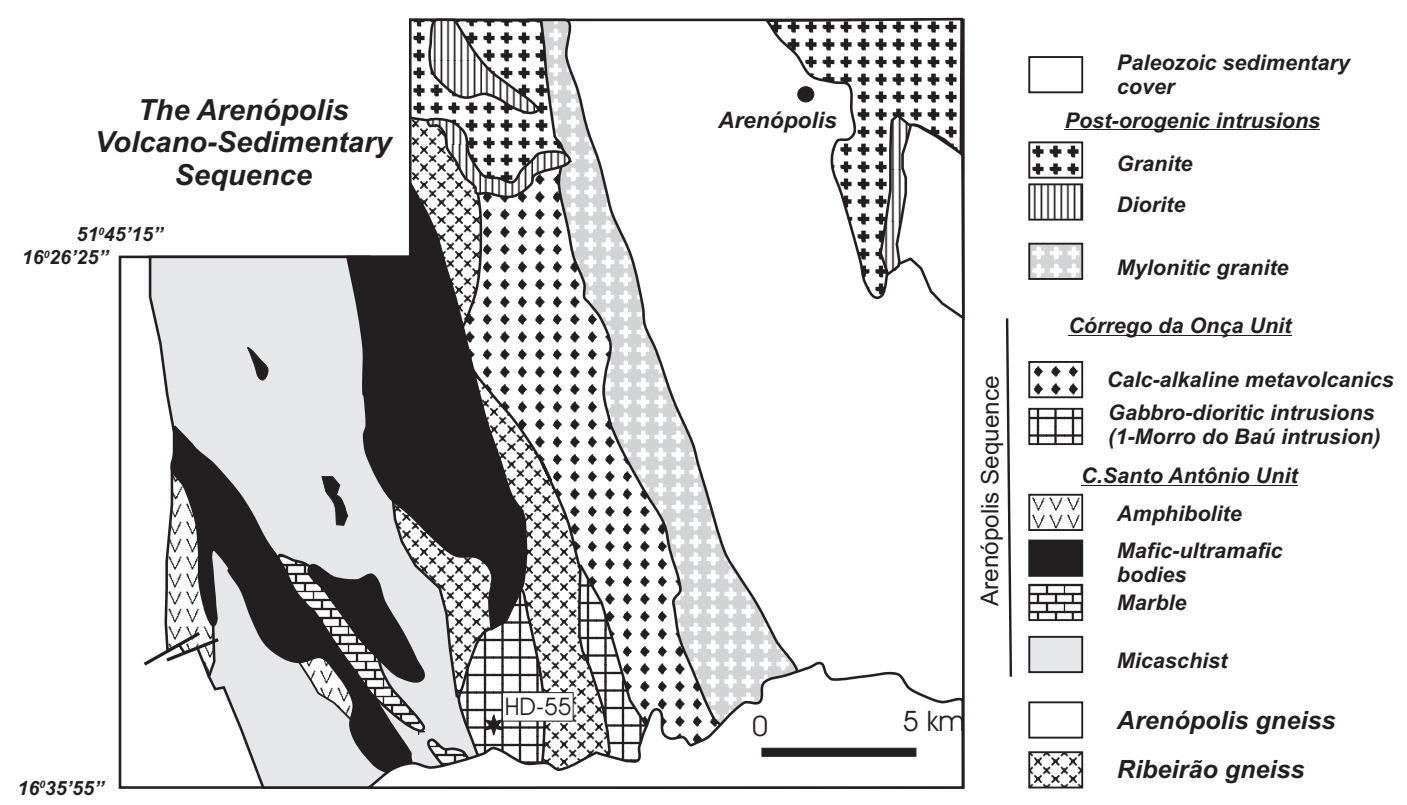

Fig. 2 - Geological map of the Arenópolis volcano-sedimentary sequence (Pimentel and Fuck 1986). 
dacites and metarrhyolites, and has major and trace element characteristics which are very similar to primitive island arc associations. Amphibolites are chemically similar to low-K tholeiites of immature, intraoceanic volcanic arcs. Relict igneous features such as pillow structures, porphyritic and tuffaceous textures have been described and are not uncommon, despite strong deformation and upper greenschist to lower amphibolite facies metamorphism. Previous U-Pb geochronological data for meta-rhyolites have indicated the age of ca. $930 \mathrm{Ma}$, based on significantly discordant zircon analyses (Pimentel et al. 1991). Titanites from the same rock sample have a U-Pb age of ca. $600 \mathrm{Ma} . \varepsilon_{\mathrm{Nd}}(\mathrm{T})$ values are very positive, ranging from ca. +5.0 to +3.0 indicative of the very primitive nature of the original magmas (Pimentel and Fuck 1992).

2. The Córrego Santo Antônio Unit occupies the western portion of the Arenópolis volcanosedimentary sequence and consists of a complex association of micaschists with garnet, staurolite, kyanite and sillimanite, biotite marble, minor quartzite, calc-silicate rocks, gondite, and tholeiitic amphibolites associated with mafic-ultramafic bodies. The latter are made of serpentinite, metaperidotite, metapyroxenite and metagabbro. This sequence has been interpreted as an accretionary prism and the plutonic mafic-ultramafic bodies as ophiolite fragments (Pimentel and Fuck 1986).

The geological units above are separated from each other by a narrow strip of paleoproterozoic (ca. $1.8 \mathrm{Ga}$ ) gneissic rocks, known as the Ribeirão gneiss (Pimentel 1992). These are banded gneissic rocks of granitic composition which have Archean $\mathrm{T}_{\mathrm{DM}}$ model ages, ranging between ca. $2.8 \mathrm{Ga}$ to 3.8 Ga (Pimentel 1992). REE patterns show strong LREE/HREE fractionation, with $(\mathrm{La} / \mathrm{Yb})_{\mathrm{N}}$ of ca. 51, similar to typical Archean calc-alkaline granitoids. Mafic pods in the gneissic rocks have younger model ages (ca. $1.28 \mathrm{Ga}$ ) and might represent dis- rupted mafic dykes which invaded the gneisses during the Neoproterozoic (Pimentel 1992). The biotite gneisses have been intensely affected by a Neoproterozoic re-homogenization event, as indicated by the whole-rock Sm-Nd isochron age of ca. $820 \mathrm{Ma}$ $\left(\varepsilon_{\mathrm{Nd}}(\mathrm{T})\right.$ of ca. -26$)$.

\section{MATERIALS AND METHODS}

\section{Analytical Procedures}

Zircon concentrates were extracted from ca. $5 \mathrm{~kg}$ rocks sample, using a gravimetric (DENSITESTß dry shaking table) and magnetic (Franz isodynamic separator) techniques at the Geochronology Laboratory of the University of Brasília. No heavy liquids were used. Final purification was achieved by hand picking using a binocular microscope.

Ion microprobe analyses were carried out using SHRIMP I at the Research School of Earth Sciences, Australian National University, Canberra, Australia. Zircon grains were mounted in epoxy resin and polished. Transmitted and reflected light microscopy, as well as scanning electron microscope cathodoluminescence imagery was used to investigate the internal structures of the zircon crystals prior to analysis. Data were collected and reduced as described by Williams and Claesson (1987) and Compston et al. (1992). Uncertainties reported in Table I are given at $1 \sigma$ level, and final age is quoted at $95 \%$ confidence level. Reduction of raw data and age calculation were carried out using Squid 1.02 and Isoplot-Ex (Ludwig 2001a,b). U/Pb ratios were referenced to the RSES standard zircon FC1 (1099 Ma, $\left.{ }^{* 206} \mathrm{~Pb} /{ }^{238} \mathrm{U}=0.1859\right)$. $\mathrm{U}$ and $\mathrm{Th}$ concentrations were determined relative to those measured in the RSES standard SL13.

Sm-Nd isotopic analyses followed the method described by Gioia and Pimentel (2000) and were carried out at the Geochronology Laboratory of the University of Brasília. Whole rock powders (ca. $50 \mathrm{mg}$ ) were mixed with ${ }^{149} \mathrm{Sm}^{-150} \mathrm{Nd}$ spike solution and dissolved in Savillex capsules. Sm and $\mathrm{Nd}$ extraction of whole-rock samples followed conventional cation exchange techniques, using teflon 


\section{TABLE I}

Summary of SHRIMP U-Pb data on zircons from sample HD55.

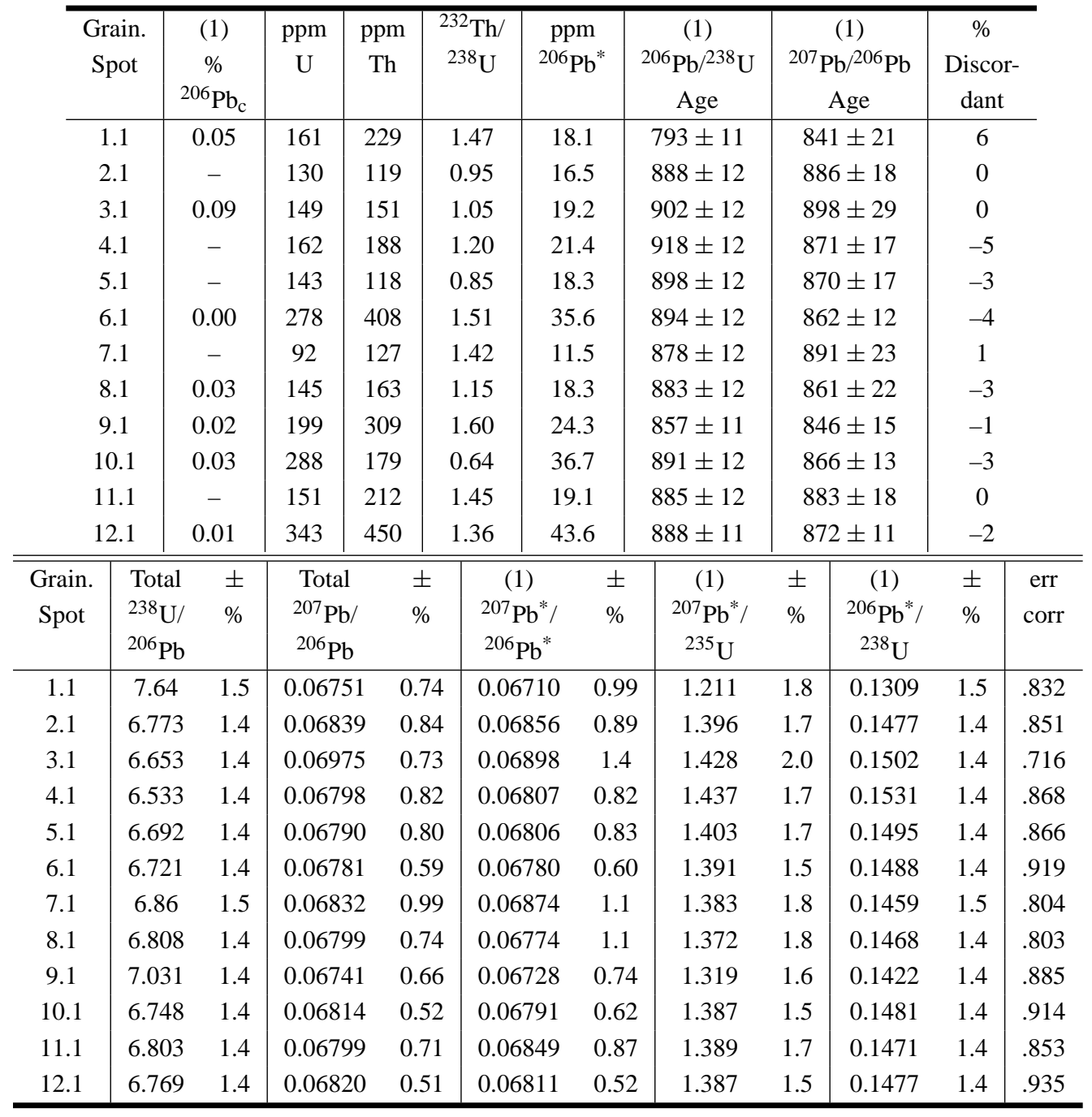

Errors are 1-sigma; $\mathrm{Pb}_{\mathrm{c}}$ and $\mathrm{Pb}^{*}$ indicate the common and radiogenic portions, respectively. Error in Standard calibration was $0.47 \%$ (not included in above errors but required when comparing data from different mounts). (1) Common $\mathrm{Pb}$ corrected using measured ${ }^{204} \mathrm{~Pb}$. All zircons are pink, prismatic, long $(5: 1)$, clear, without cracks or inclusions.

columns containing LN-Spec resin (HDEHP - diethylhexil phosphoric acid supported on PTFE powder). Sm and Nd samples were loaded on Re evaporation filaments of double filament assemblies and the isotopic measurements were carried out on a multi-collector Finnigan MAT 262 mass spectrometer in static mode. Uncertainties for $\mathrm{Sm} / \mathrm{Nd}$ and
${ }^{143} \mathrm{Nd} /{ }^{144} \mathrm{Nd}$ ratios are better than $\pm 0,1 \%(1 \sigma)$ and $\pm 0.005 \%(1 \sigma)$ respectively, based on repeated analyses of international rock standards BHVO-1 and BCR-1. ${ }^{143} \mathrm{Nd} /{ }^{144} \mathrm{Nd}$ ratios were normalized to ${ }^{146} \mathrm{Nd} /{ }^{144} \mathrm{Nd}$ of 0.7219 and the decay constant $(\lambda)$ used was $6.54 \times 10^{-12}$. 


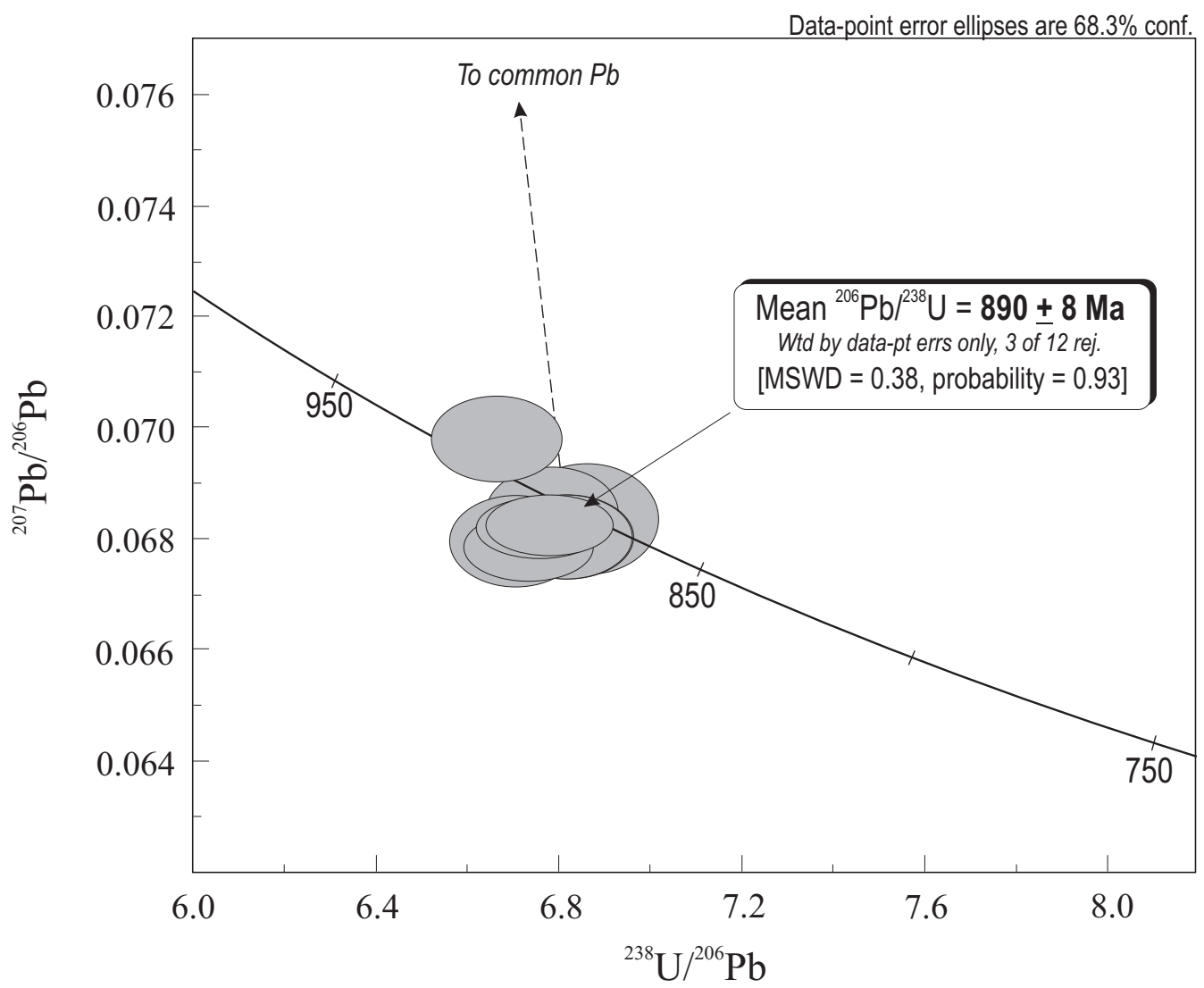

Fig. 3 - U-Pb SHRIMP data for the Morro do Baú mafic intrusion.

\section{RESULTS AND DISCUSSION}

Zircons separated from a gabbro sample of the Morro do Baú intrusion (HD-55) consist of pink, long, prismatic crystals, with thick zoning apparent from the cathodoluminescence images, which is a typical internal feature of zircon crystallized from mafic magmas. No core-overgrowth relationships are observed. $\mathrm{Th} / \mathrm{U}$ ratios of zircon grains from the Morro do Baú gabbro are mostly greater than 1.0 (Table I), typical of crystals formed in mafic magmas.

Analysis of twelve zircon grains resulted in nine concordant analytical points which yielded the mean ${ }^{206} \mathrm{~Pb} /{ }^{238} \mathrm{U}$ age of $890 \pm 8 \mathrm{Ma}(\mathrm{MSWD}=$ 0.38 ).

The age is slightly younger that the conventional $\mathrm{U}-\mathrm{Pb}$ zircon age of ca $930 \mathrm{Ma}$ found for the Córrego da Onça volcanic unit (Pimentel et al. 1991). However, that age was calculated with a regression through discordant analyses and also included analytical points of ca. 600 metamorphic titanite. It was assumed therefore, that all $\mathrm{Pb}$ loss was episodic, and due to the Brasiliano metamorphism. There is, therefore, a large uncertainty in that upper intercept age, and the ${ }^{207} \mathrm{~Pb} /{ }^{206} \mathrm{~Pb}$ ages of the individual zircon analyses, of ca. $900 \mathrm{Ma}$, might be a better estimate for the crystallization of the volcanics of the Córrego da Onça Unit. At this stage, therefore, it can be assumed only that the Morro do Baú intrusion is roughly coeval with the volcanic rocks, or perhaps maybe slightly younger than the supracrustal rocks, as suggested by the amphibolite xenoliths, supporting field observation described by Pimentel and Fuck (1986).

$\mathrm{Sm}-\mathrm{Nd}$ isotopic characteristics of the gabbro- 
diorite, however, are completely different when compared with the Córrego da Onça volcanics ( $\mathrm{Sr}$ and $\mathrm{Nd}$ isotopic data are in table in the inset of Figure 4). It shows strong contamination of the original mafic magma with older sialic rocks, as indicated by the Archean $\mathrm{T}_{\mathrm{DM}}$ of ca. $2.8 \mathrm{Ga}$ and the negative $\varepsilon_{\mathrm{Nd}}(\mathrm{T})$ value of ca. -9.7 (Figure $\left.4 \mathrm{~A}\right)$. The $\mathrm{Sr}$ vs. $\mathrm{Nd}$ isotope diagram (Figure 4B) illustrates the initial $\mathrm{Sr}$ and $\mathrm{Nd}$ isotopic composition of the Morro do Baú gabbro indicating a significant amount of contamination of the original mafic magma with ancient sialic material.

The Morro do Baú gabbro was, therefore, emplaced into and contaminated with the Ribeirão gneisses, concurring with the observations of Pimentel (1992), which suggested that mafic pods in the gneissic rocks may represent disrupted and strongly deformed younger (Neoproterozoic) mafic dykes.

\section{CONCLUSIONS}

The new U-Pb and Sm-Nd data for the Morro do Baú mafic intrusion in the southern part of the Arenópolis volcano-sedimentary sequence allow the following conclusions regarding its tectonic evolution:

- The original mafic plutonic rocks crystallized at $890 \pm 8 \mathrm{Ma}$ and are roughly coeval, or only slightly younger than the calc-alkaline volcanics of the Córrego da Onça Unit;

- Differently from the calc-alkaline volcanic rocks, which are juvenile, with positive $\varepsilon_{\mathrm{Nd}}(\mathrm{T})$ and $\mathrm{T}_{\mathrm{DM}}$ ages of ca. 0.9-1.0 Ga, the Morro do Baú gabbro is strongly contaminated with older (Archean) continental crust. The Archean contaminant is represented by the allochthonous sliver of gneissic rocks (Ribeirão gneiss) which are country-rocks of the mafic intrusion;

- The emplacement of mafic magmas into the Ribeirão gneisses might have been responsible for the re-homogenization of $\mathrm{Nd}$ isotopic system of these rocks, as suggested by their $\mathrm{Sm}-\mathrm{Nd}$ isochron of ca. $820 \mathrm{Ma}$;
- The emplacement age of the Morro da Baú gabbro establishes a lower limit for the age of tectonic accretion of the Ribeirão allochthonous gneiss to the younger rock units. Considering that the Goiás Magmatic Arc started its evolution in intraoceanic island arcs not much earlier than the emplacement of the mafic intrusion, it is suggested that the tectonic accretion of the Ribeirão gneisses took place very early in the history of the island arc, and may represent a fragment of a microcontinent which amalgamated with the island arc between ca. 920 and $890 \mathrm{Ma}$.

\section{ACKNOWLEDGMENTS}

The authors are grateful to CNPq for continuous support and doctorate scholarship to MHBMH.

\section{RESUMO}

A seqüência vulcano-sedimentar de Arenópolis, localizada na porção sul do Arco Magmárico de Goiás, inclui uma associação de rochas vulcânicas calci-alcalinas de arco com ca. 900 Ma de idade, constituída de rochas variando em composição entre basaltos e riolitos, metamorfisados em fácies xisto verde a anfibolito.

Pequenos corpos sub-vulcânicos de gabros a granitos calci-alcalinos são também reconhecidos. A intrusão do Morro do Baú é a maior dessas intrusões, compreendendo dioritos e gabros. Cristais de zircão separados de uma amostra de gabro e analisados no SHRIMP I indicaram a idade ${ }^{206} \mathrm{~Pb} /{ }^{238} \mathrm{U}$ média de $890+/-8 \mathrm{Ma}$, mostrando que a intrusão é grosseiramente contemporânea, ou talvez um pouco mais jovem que as rochas vulcânicas.

Ao contrário das rochas metavulcânicas, que são juvenis, a composição isotópica de $\mathrm{Nd}$ do gabro do Morro do Baú indica forte contaminação com material siálico arqueano ( $\mathrm{T}_{\mathrm{DM}}$ de $2.8 \mathrm{Ga}$ e Epsilon Nd $_{\mathrm{N}}(\mathrm{T})$ igual a-9.7), representado na área por uma pequena fatia tectônica de rocha gnáissica arqueana/paleoproterozóica (gnaisse Ribeirão), e que representa a rocha encaixante da intrusão gabro-diorítica.

A idade de cristalização de ca. 890 Ma representa, portanto, um limite mínimo para a acresção tectônica do gnaisse Ribeirão às rochas mais jovens da seqüência de 

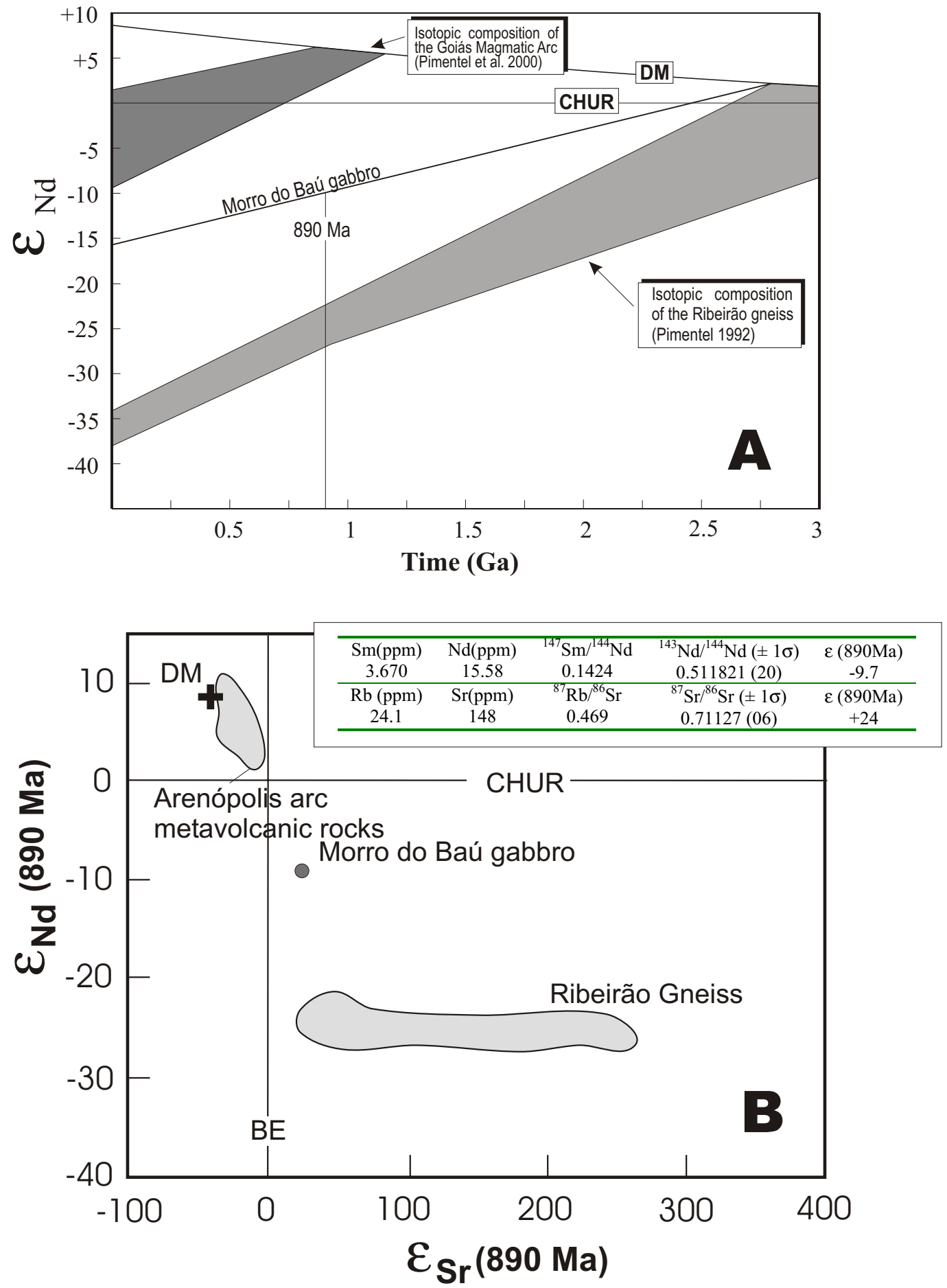

Fig. 4 - Nd and Sr isotopic characteristics of the Morro do Baú mafic intrusion, compared with the Ribeirão gneiss and volcanic rocks of the Goiás Magmatic Arc. 
Arenópolis. Os dados sugerem que esse evento foi precoce na evolução da seqüência vulcano-sedimentar de Arenópolis, provavelmente entre ca. 920 e 890 Ma.

Palavras-chave: Arco Magmático de Goiás, Arenópolis, U-Pb SHRIMP, magmatismo básico, contaminação crustal.

\section{REFERENCES}

Compston W, Williams IS, KirschVink JL, Zhang Z AND GuOGan MA. 1992. Zircon U-Pb ages for the Early Cambrian time-scale. J Geol Soc London 149: 171-184.

Fuck RA, Pimentel MM and D'El Rey Silva LJH. 1994. Compartimentação tectônica da porção oriental da Província Tocantins. In: Cong. Brasil. Geol., 38., Anais... Balneário Camboriú-SC, SBG, p. 215-216.

Gioia SMCL and Pimentel MM. 2000. The Sm-Nd isotopic method in the Geochronology Laboratory of the University of Brasília. An Acad Bras Cienc 72: 219-245.

Junges SL, Pimentel MM and Moraes R. 2002. Nd isotopic study of the Neoproterozoic Mara Rosa Arc, central Brazil: implications for the evolution of the Brasília Belt. Precamb Res 117: 101-118.

Ludwig KR. 2001a. Squid 1.02. A user's manual. BGC Special Publ. 2., Berkeley, 19p.

LuDwiG KR. 2001b. User's manual for Isoplot/Ex v. 2.47. A geochronological toolkit for Microsoft Excel. BGC Special Publ. 1a, Berkeley, 55p.

Pimentel MM. 1992. Reajuste do sistema isotópico SmNd durante o Neoproterozóico em gnaisses do oeste de Goiás. Rev Bras Geocienc 22: 1-7.

Pimentel MM AND Fuck RA. 1986. Geologia da seqüência vulcano-sedimentar de Arenópolis (GO). Rev Bras Geocienc 16: 217-223.
Pimentel MM And Fuck RA. 1987. Origem e evolução das rochas metavulcânicas e metaplutônicas da região de Arenópolis (GO). Rev Bras Geocienc 17: 2-14.

Pimentel MM and Fuck RA. 1992. Neoproterozoic crustal accretion in Central Brazil. Geology 20: 372379.

Pimentel MM, Heaman L and Fuck RA. 1991. Zircon and sphene U-Pb geochronology of upper Proterozoic volcanic arc rock units from southwestern Goiás, Central Brazil. J S Am Earth Sci 4: 295-305.

Pimentel MM, Fuck RA And Alvarenga CJS. 1996. Post-Brasiliano (Pan-African) high-K granitic magmatism in central Brazil: the role of Late Precambrian/early Paleozoic extension. Precamb Res 80: 217-238.

Pimentel MM, Whitehouse MJ, Viana MG, Fuck RA and Machado N. 1997. The Mara Rosa arc in the Tocantins Province: Further evidence for Neoproterozoic crustal accretion in central Brazil. Precamb Res 81: 299-310.

Pimentel MM, Fuck RA AND Gioia SMCL. 2000a. The Neoproterozoic Goiás Magmatic Arc, Central Brazil: a review and new $\mathrm{Sm}-\mathrm{Nd}$ isotopic data. $\mathrm{Rev}$ Bras Geocienc 30: 35-39.

Pimentel MM, Fuck RA, Jost H, Ferreira Filho CF and Araúso SM. 2000b. The basement of the Brasília Fold Belt and the Goiás Magmatic Arc. In: Cordani UG, Milani EJ, Thomaz Filho A and Campos DA. (Eds). Tectonic Evolution of South America. Rio de Janeiro, 31st International Geological Congress, p. 190-229.

Williams IS and Claesson S. 1987. Isotopic evidence for the provenance and Caledonian metamorphism of high grade paragneisses from the Seve Nappes, Scandinavian Caledonides: ion microprobe zircon U-Th-Pb. Contrib Mineral Petr 97: 205-217. 